\title{
Akdeniz Meyve Sineği (Ceratitis capitata Wiedemann) (Diptera: Tephritidae)' nin Hünnap Bahçesindeki Popülasyon Dalgalanmaları ve Zararı
}

\section{Sergen GÜLCÜOĞLU ${ }^{* 1}$, Hüseyin BAŞPINAR ${ }^{1}$}

\author{
${ }^{1}$ Aydın Adnan Menderes Üniversitesi, Ziraat Fakültesi, Bitki Korumu Bölümü, Aydın
}

Öz: Bu çalışma hünnap bahçesindeki Akdeniz meyve sineği,(Ceratitis capitata Wiedemann) (Diptera: Tephritidae)' nın popülasyon dalgalanmaları ve zararını saptamak amacıyla yapılmıştır. Çalışma 2017-2018 yıllarında yürütülmüş olup, popülasyon dalgalanmaları ve zararı Çine ilçesindeki bir hünnap bahçesinde çalışılmışı̆ı. Laboratuvar çalışmaları ise $25 \pm 2{ }^{\circ} \mathrm{C}$ sıcaklık \%60 \pm 10 orantılı nem ve 16:8 saat (aydınlık: karanlık) aydınlatmalı iklim odalarında yürütülmüştür.

Bu çalışmada, zararlının bahçe içerisinde ortaya çııışı Haziran ayında gerçekleşmiş ve Kasım-Aralık aylarında ise en düşük düzeyine gerilemiştir. Buna göre, ergin bireylerin hünnap bahçesinde görülme süresi yaklaşık 5 ay kadardır. C. capitata' nın popülasyon değişimleri yıllar esas alınarak incelendiğinde 2017 yılında en yüksek düzeye Ekim ayı başında, 2018 yılında ise en yüksek düzeye Ağustos ayı ortalarında ulaşmıştır. C. capitata' nın meyvelerdeki zarar oranı incelendiğinde en yüksek zararın \%45.7 en düşük zararın \%16.7 olduğu, ortalama olarak ise \%29.3 oranında bir zarar oluşturduğu tespit edilmiştir. Akdeniz meyve sineğinin hünnap meyvesi içerisindeki gelişme süresi üzerine laboratuvarda yapılan çalışmada ise, yumurtadan ergine ortalama 23.6 günde ulaştığı saptanmıştır.

Anahtar Kelimeler: Akdeniz meyve sineği, Ceratitis capitata, hünnap, Ziziphus jujuba

Population Dynamics and Damage of The Mediterranean Fruit Fly (Ceratitis capitata Wiedemann) (Diptera: Tephritidae) In a Jujube Orchard

\begin{abstract}
It was aimed in this study to determine the population dynamics and damage of Mediterranean fruit fly, Ceratitis capitata (Wiedemann) (Diptera: Tephritidae) in a jujube orchard. The study was conducted in Çine district in 2017-2018. Laboratory studies were carried out at $25 \pm 2{ }^{\circ} \mathrm{C}$ temperature $\% 60 \pm 10$ relative humidity and L16: D 8-h photoperiod in a climate chamber. In this study, the emergence of the pest in the orchard took place in June, and the population decreased to zero level in November-December. According to the observation results, the adults maintained in the jujube orchard about 5 months, from June on. When the population dynamics of $C$. capitata were examined during the season, it peaked to the highest level in October in 2017 and in mid-August in 2018. It was found that the highest damage was $45.7 \%$, and the lowest damage was $16.7 \%$ and average damage was $29.3 \%$. In the laboratory study on the development time of the Mediterranean fruit fly in the jujube fruit, it was determined that duration from egg to adult reached in average 23.6 days.
\end{abstract}

Keywords: Mediterranean fruit fly, Ceratitis capitata, jujube, Ziziphus jujuba

\section{GiRiş}

Hünnap (Ziziphus jujuba Miller) Çin orijinli bir bitki olup 4000 yıldan beri yetiştirilmektedir. Bitkinin anavatanı olan Çin dışında diğer yayılış alanları Rusya, Hindistan, Ortadoğu, Anadolu, Güney Avrupa ve Kuzey Afrika'dır. Çin'de şeftali, kayısı, erik ve armut gibi en değerli 5 meyveden biri olduğu düşünülmektedir (Yao, 2012). Dünyadaki hünnap üretiminin yaklaşık \%90'lık payı Çin tarafından karşılanmaktadır (Li ve ark., 2005). Hünnap ağaçları morfolojik olarak dik ve tırmanıcı olup bitkiler ağaç ve çalı formunda, boyları 7-10 metreyi bulmaktadır ve ekstrem toprak ve iklim koşullarına uyumludur (Davis, 1967; Ecevit ve ark., 2002; Özkan, 2017). Türkiye İstatistik Kurumu verilerine göre hünnap üretimi bazı illerimizde giderek artmaktadır. Son 2018 yılı incelendiğinde en çok meyvelik bulunan ilimiz Manisa olmasına rağmen en çok verim alınan ilimiz ise Amasya olmuştur (Tüik, 2019).

Dünyada önemli zararlılardan biri olarak kabul edilen Ceratitis capitata Wiedemann (Diptera: Tephritidae) (Akdeniz meyve sineği)' nın başta ılıman ve subtropik meyveler, bazı sebzeler ve süs bitkileri olmak üzere 260'dan fazla konukçu bitkide zararlı olduğu bildirilmiştir (Weems, 1981).

Zararlının orijininin Afrika'nın doğusu ve tropikal bölgeleri olduğu kabul edilmektedir. Bu zararlı; dünyada tropik ve subtropik tüm bölgelere yayılmış olan ve diğer meyve sineklerine göre nispeten serin iklimli bölgelere adapte olabilmektedir. Turunçgiller, nar, Trabzon hurması, erik, şeftali, nektarin ve incir gibi çok sayıda önemli ticari meyve türlerinde zarar yapmaktadır ve bu nedenle birinci derecede ekonomik öneme sahip bir zararlı durumuna gelmiştir (Demirdere, 1961).

Birçok ülkede karantinaya tabi olan Akdeniz meyve sineği, ürünün bu zararlı ile bulaşık olması durumunda ihracat yapılan ülkeler tarafından geri çevrilmesine sebep olmaktadır (Başpınar ve ark., 2009).

*Sorumlu Yazar: s.qulcuoglu@hotmail.com. Bu çalışma yüksek lisans tez ürünüdür.

Geliş Tarihi: 21 Ekim 2019

Kabul Tarihi: 25 Aralık 2020 
Ülkemizde Akdeniz meyve sineği ile ilgili yapılmış birçok çalışma mevcuttur (Demirdere, 1961; illeri, 1961; Akman ve Zümreoğlu, 1973; Tezcan ve Zümreoğlu, 1986; Zümreoğlu, 1990; Özkan, 1993; Başpınar ve ark., 2009). Ancak yapılan literatür çalışmasında hünnap meyvesinin konukçu olarak bildirilmesine karşın, hünnap bahçelerinde Akdeniz meyve sineği ile ilgili yapılmış herhangi bir çalışmaya rastlanmamıştır.

Bu nedenle bu çalışma ele alınmış olup, Aydın ilindeki bir hünnap bahçesinde Akdeniz meyve sineğinin bahçe içerisinde ortaya çıkış zamanı, popülasyon değişimleri, meyvedeki zarar oranı ve laboratuvarda meyve içerisindeki gelişme süresi çalışılımıstır.

\section{MATERYAL VE YÖNTEM}

Çalışmanın ana materyalini Aydın ili Çine ilçesine bağlı Bahçearası mahallesinde bulunan 10 yaşındaki 450 ağaç içeren bir hünnap bahçesi ve Akdeniz meyve sineği oluşturmaktadır. Bu hünnap bahçesi sıra araları $5 \times 5 \mathrm{~m}$ olmak üzere tesis edilmiş olup damlama sulama sistemi ile sulanmaktadır. Hasat üç defada yapılmakta, Ağustos sonu Eylül başında başlamakta Eylül sonunda tamamlanmaktadır.Bahçenin etrafındaki alanda ise başkaca bir meyve bahçesi bulunmamaktadır.Bunun yerine mısır ve pamuk tarımı yapılmaktadır. Bahçe izole durumdadır. Çalışmalar 2017-2018 yıllarında gerçekleştirilmiştir.

Akdeniz meyve sineğinin çıkış zamanı ve popülasyon gelişiminin izlenmesi

Hünnap bahçesinde Akdeniz meyve sineğinin çıkış zamanı ve popülasyon gelişiminin izlenmesine yönelik örneklemeler yapılmıştır. Bunun için, bahçeye 2 adet delta tipi feromon tuzağı yerden yaklaşık $1.5 \mathrm{~m}$ yüksekliğindeki ağacın uygun olan dallarına, güney yönüne 2017 ve 2018 yıllarında haziran başından başlayarak asılmıştır.

Bu tuzaklarda yakalanan ergin bireyler haftalık olarak sayılmış ve değerler kaydedilmiştir. Tuzak feromon kapsülleri (Russel IPM: PH-180-1 SR) 5 haftada bir yenileriyle değiştirilmiş̧tir.

Böylece, bahçedeki Akdeniz meyve sineğinin çıkış zamanı ve popülasyon seyri izlenmiştir. Popülasyon takibi, Akdeniz meyve sineğinin bahçedeki popülasyonu sıfır düzeyine gelinceye kadar yapılımıştır.

\section{Akdeniz meyve sineğinin zararının saptanması}

Bunun için bahçenin kenar kısmında 10 ağaç bırakılarak burada herhangi bir mücadele işlemi yapılmamıştır. Ayrıca, bahçe içerisinde $C$. capitata mücadelesi yapılan 10 ağaç karşılaştırma amaçlı olarak belirlenmiştir. Bu ağaçların güney kısmında birer dalındaki meyveler zararlının ortaya çıkışıla birlikte gözle incelenmiş ve vuruklu meyve kontrolleri yapılmıştır. Zararın başlamasıyla birlikte, her hafta zarar gören meyveler koparılmış ve sayıları kaydedilmiştir. Hasat zamanı bu daldaki sağlam meyveler 146 sayılmış ve toplam meyve üzerinden zarar görmüş meyvelerin sayıları dikkate alınarak zarar oranı belirlenmiştir. Mücadele uygulanan ve uygulanmayan ağaçlardaki zarar oranları SPSS programıyla t-testi uygulanarak karşılaştırılmıştır.

Akdeniz meyve sineğinin meyve içerisindeki gelişme süresi Bu çalışma $25 \pm 2^{\circ} \mathrm{C}$ sıcaklık $\% 60 \pm 10$ orantılı nem ve $16: 8$ saat (aydınlık: karanlık) aydınlatmalı iklim odalarında yürütülmüştür.Çalışma için, bahçe içerisinden 100 adet sağlam hünnap meyvesi toplanarak bunlar 10' arlı gruplar halinde 10 tekerrürlü olarak plastik kavanozlara bırakılmıştır ve 2-3 gün bekletildikten sonra her birinin zararlıdan ari olduğu stereo binoküler mikroskop altında incelenerek teyit edilmiştir. Bu kavanozların her birine doğadan toplanmış meyvelerden elde edilen 15-20 adet Akdeniz meyve sineği erginleri konularak bu meyveler üzerinde 2 gün tutulmuştur. Daha sonra bu meyveler ayrilarak, laboratuvarda küçük kavanozlar içerisinde ergin çıkışına kadar bekletilmiştir. Böylece Akdeniz meyve sineğinin hünnap meyvesi içerisindeki yumurtadan ergine kadar gelişme süresi belirlenmiştir.

\section{BULGULAR VE TARTIŞMA}

Akdeniz meyve sineğinin çıkış zamanı ve popülasyon gelişiminin izlenmesi

Popülasyon değişimleri yıllar esas alınarak 2017 yılı değerleri incelendiğinde (Şekil 1), örnekleme yapılan bahçede popülasyondaki ilk bireyler meyvelerin üzüm danesi büyüklüğünde olduğu haziran ayı ortalarında minimum seviyelerinde görülmeye başlamıştır. Özkan (1993) tarafından yapılan çalışmada C. capitata erginleri ilk olarak Haziran başında şeftali, kayısı ve elma bahçelerinde görüldüğü bildirilmiştir. Aynı zamanda Başpınar ve ark. (2009) yaptığı çalışmada, Kuşadası'nda şeftali bahçesinde ilk erginlerinHaziran ayında gözlemlendiğini belirtmiştir. Bu çalışmada, Ağustos ayı sonlarına kadar düşük düzeylerde seyreden popülasyon, Ağustos sonundan itibaren hızla yükselmiş̧ir. Bu yükselme dönemi bitki fenolojisi açısından da değerlendirilirse, meyvelerin olgunlaşmaya başladığı dönemle çakışmaktadır.

Popülasyon 21 Eylül 2017 tarihinde ilk tepe noktasını oluşturmuş ve hemen sonra Eylül sonuna kadar hızlı bir düşüş göstermiştir. Daha sonra hızla yükselen popülasyon Ekim ayının ilk haftasında ikinci tepe noktasını oluşturmuştur. En yüksek popülasyon değeri ikinci tepe noktasının olduğu 05.10.2017 tarihinde 300 birey/tuzak düzeyinde saptanmıştır (Şekil 1).

Popülasyonun oluşturduğu her iki tepe noktası da hünnap meyvesinin olgunlaşma ve hasat dönemlerine rastlamaktadır. Nitekim, C. capitata' nın zarar yaptığı başta turunçgiller olmak üzere, birçok meyvede de vurukların 
meyvenin olgunlaşmaya başlamasıyla gerçekleştiği bildirilmiştir (Başpınar ve ark., 2009).

İkinci tepe noktasından sonra hızla düşüşe geçen popülasyon değerleri hasat döneminin sonuna doğru minimum düzeylere inmiştir. Tiring (2015) tarafından yapılan çalışmada elma bahçesinde $C$. capitata 'ya ait son bireylerin hasat sonunda Kasım ayında görülmüş olması çalışmamızla benzerlik göstermektedir. Aynı zamanda Kızılyamaç (2016) da şeftali bahçesinde son erginlerin Kasım ayının son haftasında görüldüğünü bildirmiştir. Kasım ayı sonunda ise bitkinin yapraklarını dökmesi ve yağışların artması ile birlikte popülasyon sıfır düzeyine gerilemiştir. Bu dönemde, Kasım ayında ortalama sıcaklıkların Akdeniz meyve sineğinin yumurta bırakmayı kestiği sıcaklık ortalaması olan 16 ó ' nin altına düştüğü görülmektedir (Şekil 1).

Popülasyon değişimlerinin 2018 yılı değerleri incelendiğinde (Şekil 2), örnekleme yapılan bahçede ilk bireyler bir önceki yılda da olduğu gibi, Haziran ayı ortalarında görülmeye başlanmıştır. Benzer şekilde, C. capitata' nın elma bahçesindeilk olarak 20 Haziran tarihinde görüldüğü bildirilmiştir (Tiring, 2015). Aynı zamanda gerek Başpınar ve ark. (2009) ve gerekse Yunanistan' da Papadopoulos ve ark. (2001) tarafından yapılan çalışmalarda ilk ergin bireylerin kayısı bahçelerinde Haziran sonu görülmeye başlanması
GÜLCÜOĞLU S, BAŞPINAR H bunu destekler niteliktedir. Ağustos ayına kadar düşük popülasyonlarda seyreden popülasyon değerleri, bu tarihten başlayarak hızla yükselmiştir. Ağustos ortasında, ilk tepe noktasını oluşturmuş ve 14.08.2018 tarihinde yılın en yüksek popülasyon değeri olarak 315 birey/tuzak düzeyine ulaşmıştır. Daha sonra 19.09.2018 tarihine kadar göreceli olarak düşen popülasyon, bu tarihten itibaren tekrar yükselmeye başlamış ve Eylül ayısonu Ekim ayı başında ikinci bir tepe noktası oluşturmuştur. Bu ikinci tepe noktası ilkinden daha düşük bir düzeyde yaklaşık 100 birey/tuzak değerinde gerçekleşmiştir. Daha sonra popülasyon düşmeye başlamış ancak Kasım ayı başına kadar belirli bir düzeyde seyretmiştir (Şekil 2). Nitekim, bir diğer çalışmada $C$. capitata popülasyonunun meyve bahçelerinde hasadın bitmesi ile azaldığı ve popülasyonun meyveleri sararmaya ve olgunlaşmaya başlayan turunçgil bahçelerine göç ettiği bildirilmiştir (Özkan, 1993). Sıcakların bir önceki yıla göre 2018 yılında daha erken başlaması ve yıl boyunca bir önceki yıla göre daha yüksek düzeylerde seyretmesinin popülasyon artışında ve meyvelerin erken olgunlaşmasında önemli bir etken olduğu söylenebilir. Popülasyon değerleri yine bir önceki yılda olduğu gibi Kasım sonuna doğru ortalama sıcaklıkların yumurta bırakma sıcaklığının altına düşmesiyle sıfır düzeyine gerilemiştir (Şekil 2).

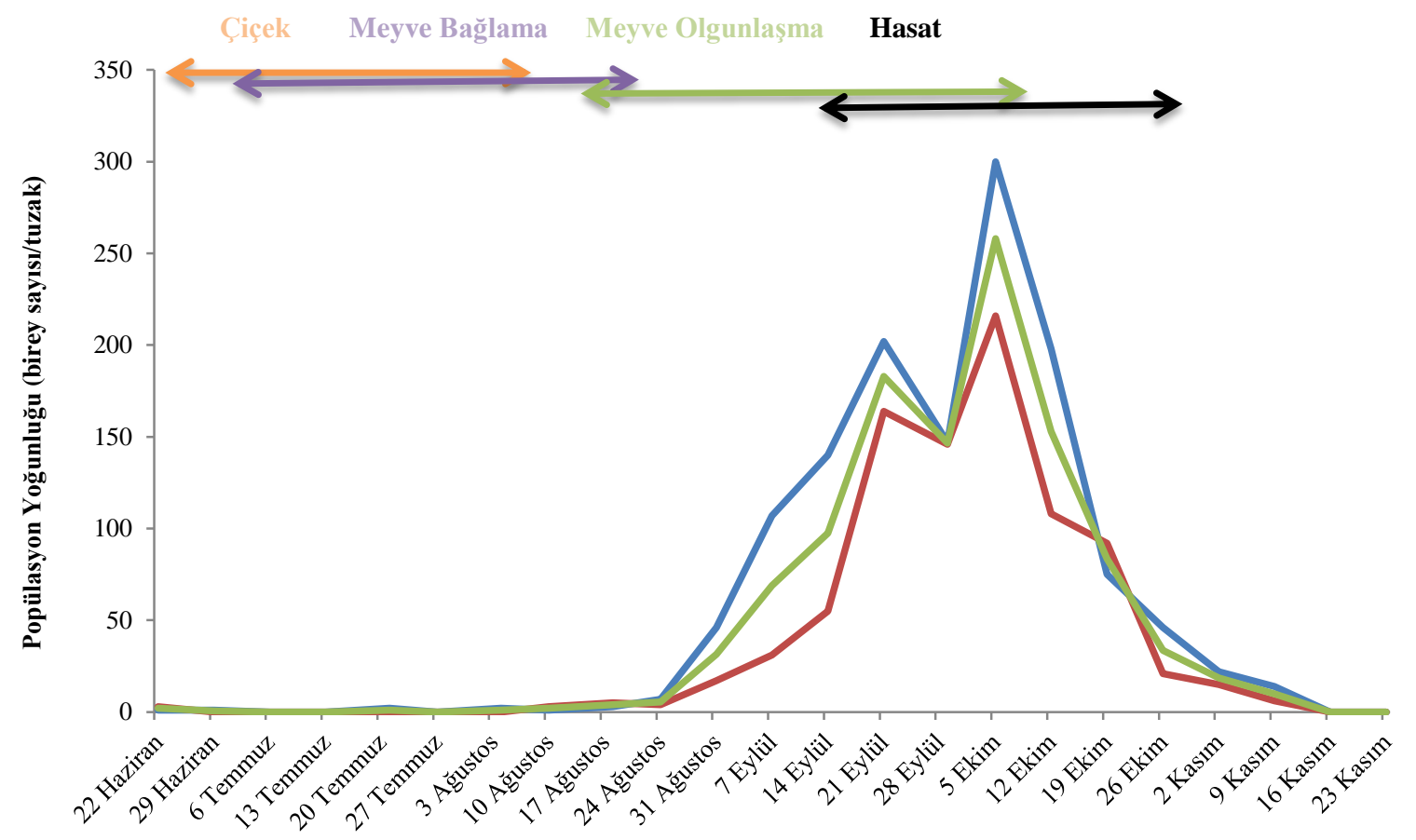

Zaman

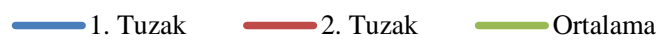




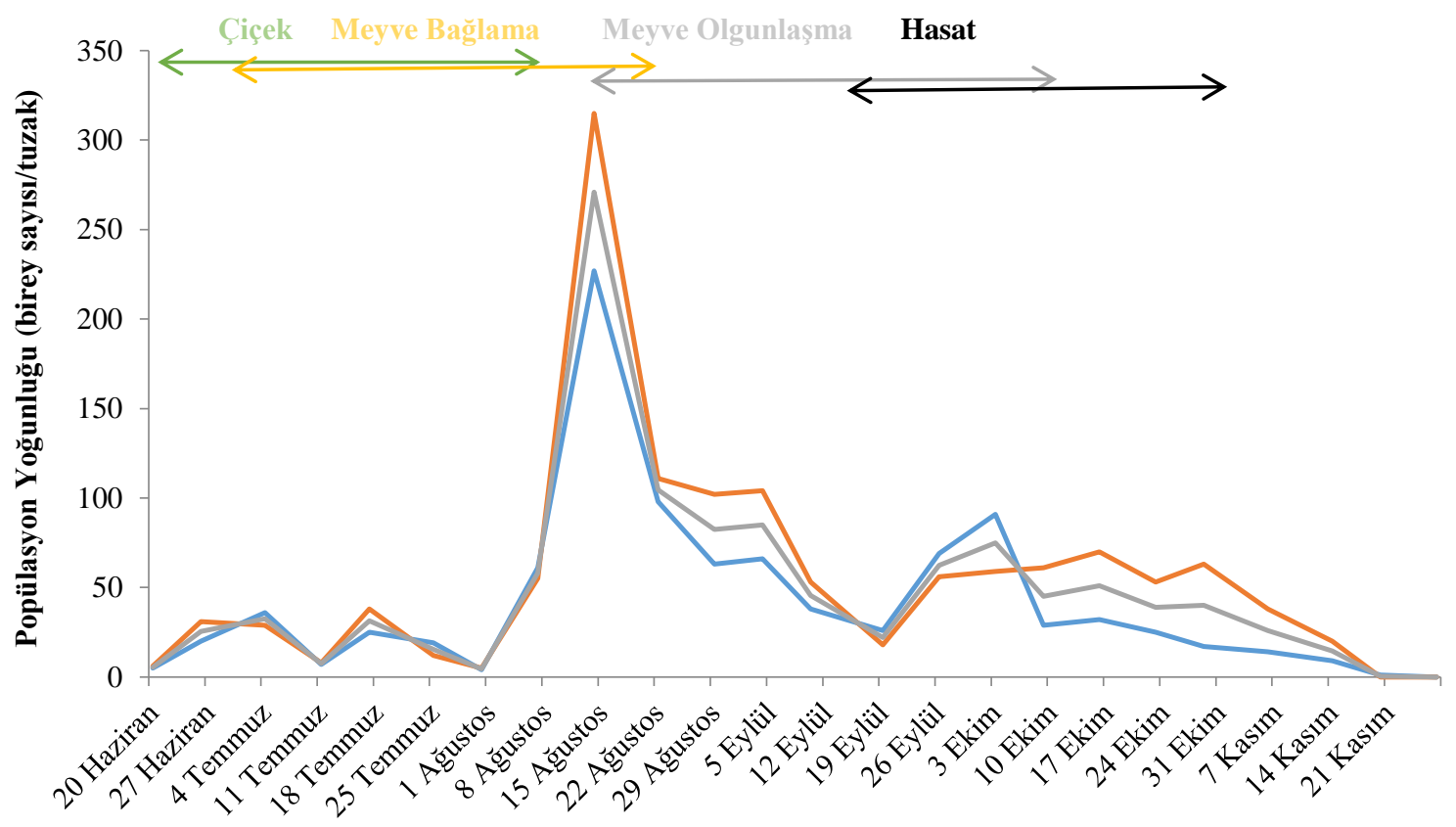

Zaman

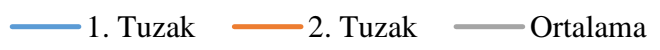

Şekil 2. Akdeniz meyve sineğinin (Ceratitis capitata) 2018 yılı popülasyon dalgalanmaları

Örnekleme yapılan bahçede her iki yıl incelendiğinde popülasyon dalgalanmalarında benzerlik göstermeyen durumlar ortaya çıkmıştır. Çalışmanın ilk yılında (2017), ilk popülasyon çıkışının olduğu Haziran ayından başlamak üzere Ağustos ayı sonuna kadar popülasyon çok düşük düzeylerde seyretmiştir. Popülasyon ancak Eylül ve Ekim aylarında en yüksek düzeylere ulaşmıştır. Üreticinin 2017 yılında haziran ayında iyi bir toprak işlemesi yaptığı ve Ayrıca temmuz ayının ilk haftasında bir ilaçlamanın yapılmış olması nedeniyle Akdeniz meyve sineği popülasyonunun Eylül ayına kadar baskı altında tutulduğu düşünülmektedir. Çalışmanın ikinci yılında ise ilkbaharda bir toprak işlemesi yapılmamış, ancak yine bir önceki yılda olduğu gibi Temmuz ayının ilk haftasında bir ilaçlama yapılmıştır. Ayrıca, meyvelerin olgunlaşmaya başladığı Ağustos ayının ikinci yarısında ve Eylül ayının ilk yarısında da olmak üzere onar gün arayla iki ilaçlama daha yapılmıştır. Bu nedenle 2018 yılının Eylül ve Ekim popülasyonları bir önceki yıla göre daha düşük düzeylerde gerçekleşmiştir. Ancak, bu sonuçlara göre C. capitata Haziran ayından başlamak üzere tüm vejetasyon dönemi boyunca görülmüş, yüksek seviyelere ulaşmış ve doğal baskı etkenleri tarafından kontrol altına alınamamıştır.

\section{Akdeniz meyve sineğinin zararının saptanması}

Yapılan çalışmada 10 ağaç üzerinden toplam zarar oranı ele alındığında zararın ağaçlardaki meyve sayılarına ve zarar görmüş meyve sayılarına bağlı olarak değiştiği görülmektedir. Zarar oranlarının saptandığı bu parselde, zararlıya karşı herhangi bir mücadele yapılmamış olup Akdeniz meyve sineğinin zarar oranları \%16.7-45.7 arasında gerçekleştiği gözlemlenmiştir (Şekil 3).

Birçok çalışmada mücadelenin yapılmaması durumunda zararın çok yüksek düzeylere ulaşabileceği bildirilmektedir. Nitekim, Başpınar ve ark. (2009) yaptıkları çalışmada Aydın ilinde Trabzon hurmasında zarar görmüş meyve oranının ortalama $\% 50$ kadar olabildiğini bildirmişlerdir. Bu çalışmada da Akdeniz meyve sineğinin zararının çok yüksek seviyelerde olduğu düşünülmektedir.

Mücadele yapılan 10 ağaç üzerinden toplam zarar oranı ele alındığında zararın yine ağaçlardaki meyve sayılarına bağıı olarak değiştiği görülmektedir.

Akdeniz meyve sineğinin cezbedici tuzak ve ilaçlama ile mücadele yapılan parselde zarar oranları \%4.6-9.3 arasında gerçekleşmiştir (Şekil 4). Yapılan bir çalışmada çekici tuzakların zarar oranını azalttığı ancak yüksek popülasyonlarda zehirli yem kısmi dal ilaçlaması ile mücadelenin desteklenmesi gerektiği bildirilmektedir 


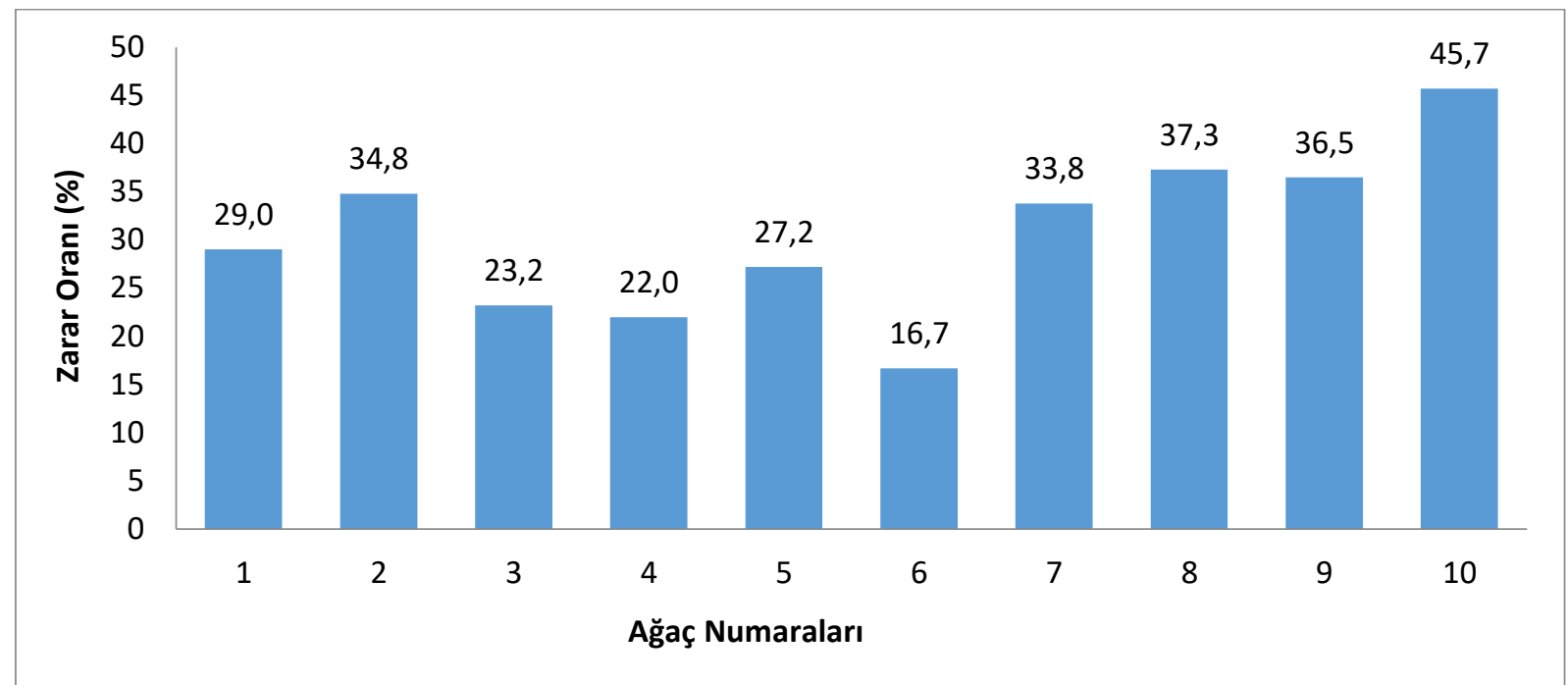

Şekil 3. Akdeniz meyve sineğinin (Ceratitis capitata) mücadele yapılmayan ağaçlardaki hünnap meyvesinde zarar oranı

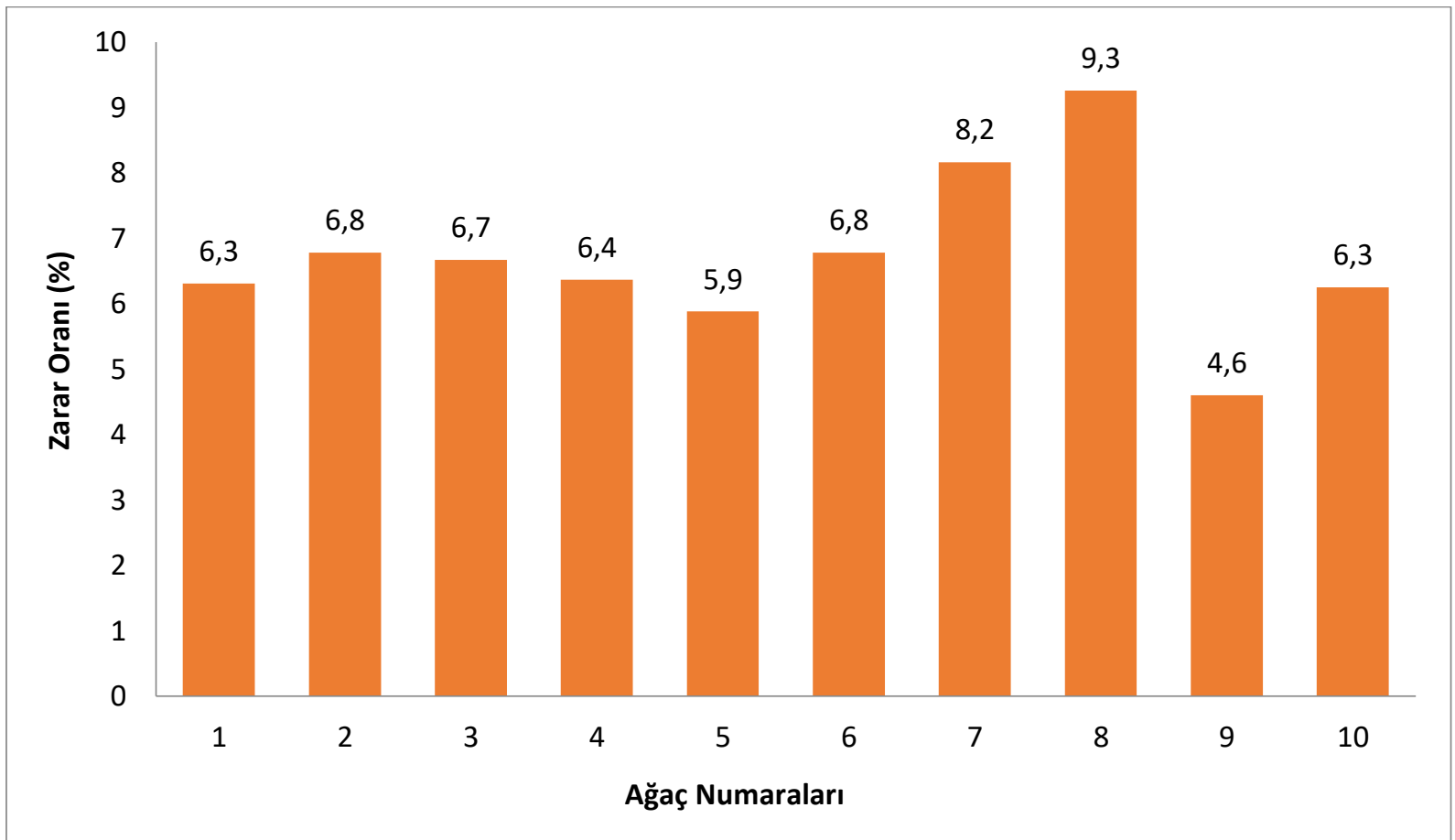

Şekil 4. Akdeniz meyve sineğinin (Ceratitis capitata) mücadele yapılan ağaçlardaki hünnap meyvesinde zarar oranı

(Başpınar ve ark., 2009). Bu çalışmada her iki mücadele yöntemi de uygulanmış olmasına karşın yine de zararın yüksek olabilecek değerlerde gerçekleştiği saptanmıştır. Bu nedenle, zararın daha da düşük düzeylere çekilebilmesinin ancak kültürel önlemlerin de uygulanmasıyla gerçekleşebileceği düşünülmektedir.

Mücadele yapılan ve yapılmayan ağaçlar karşılaştırıldığında, yapılan mücadelenin oldukça etkili olduğu görülmektedir ve bu etkinin yarattığı fark istatistiksel olarak da önemli bulunmuştur (t-testi, $\mathrm{P}=0.05$ ).
Akdeniz meyve sineğinin meyve içerisindeki gelişme süresi İklim odalarında yürütülen çalışmada Akdeniz meyve sineğinin hünnap meyvesindeki gelişim süresi incelenmiştir. On tekerrürlü olarak kurulan denemenin 5 tekerrüründen herhangi bir ergin çıkışı elde edilememiştir. Kalan beş tekerrürde ise sırasıyla; yumurtadan ergine kadar geçen süre 29.8, 21.8, 24.0, 19.3, 23.3 gün olarak belirlenmiştir. $\mathrm{Bu}$ tekerrürlerin her birinden çok az sayıda ergin birey elde edilebilmiş, hesaplamalar az sayıdaki bu bireylerden gerçekleştirilmiştir. Ortalama olarak Akdeniz meyve 
sineğinin hünnap meyvesi içerisindeki yumurtadan ergine kadar gelişme süresi 23.6 gün olarak tespit edilmiştir (Şekil 5). Denemelerde az sayıda ergin birey elde edilmesinin nedeni olarak, doğadan toplanarak getirilen ve hünnap meyveleri üzerine bırakılan ergin bireylerin meyvelerin üzerinde kaldığı iki günlük sürede çok az yumurta bırakması düşünülmektedir. Burada kısa süre içerisinde ergin dişiler laboratuvar koşullarına uyum sağlayamamış olabilirler. Ancak, yine de sınırlı olsa da bir sonuç elde edilmiştir. Bir çalışmada elma meyvesinde gelişme süreleri $24{ }^{\circ} \mathrm{C}^{\prime}$ de 26.7 gün, $28^{\circ} \mathrm{C}^{\prime}$ de 21.2 gün, Trabzon hurmasında $24{ }^{\circ} \mathrm{C}^{\prime}$ de 21.9 gün olarak saptanmıştır (Tiring, 2015). Özkan (1993) tarafından yapılan çalışmada da, 25.7 ㅇ C ortalama sıcaklıkta doğal koşullarda gelişme süreleri; Trabzon hurmasında 22.7 gün, şeftalide 24.2 gün ve kayısıda 24.8 gün olduğu tespit edilmiştir. Yapılan bazı çalışmalarda,C. capitata konukçularının meyve özlerinin ve kabuk kalınlıklarının böceğin gelişme süreleri üzerine etkileri olduğunu belirtmektedirler (Zümreoğlu, 1985; Başpınar ve ark., 2009). Çalışmamızda elde edilen bu sonuçlar hünnap meyvesinin de uygun bir konukçu olduğunu göstermektedir.

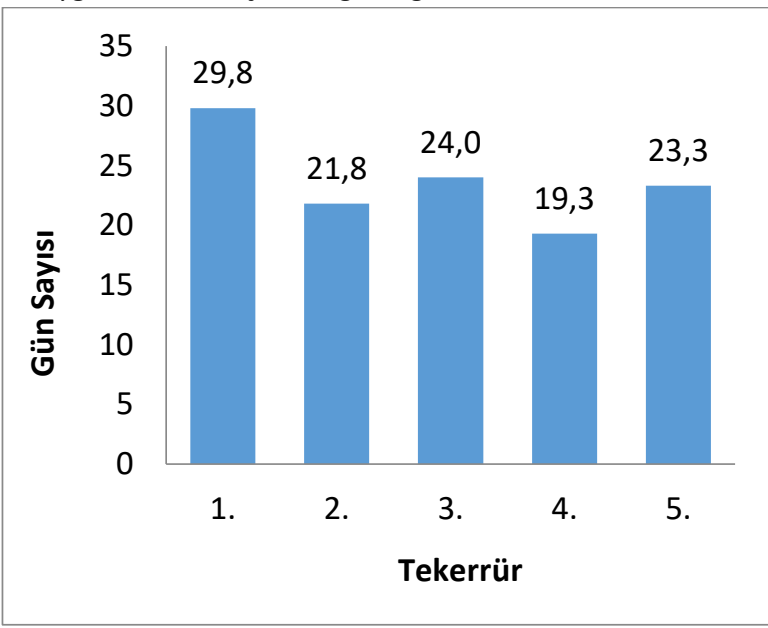

Şekil 5. Akdeniz meyve sineğinin (Ceratitis capitata) hünnap meyvesindeki gelişme süreleri(Gün)

\section{SONUÇ}

Bu çalışmada, C. capitata' nın hünnap bahçesinde Haziran ayından başlamak üzere hasat sonuna kadar popülasyon oluşturabildiği ve hünnap meyvelerinde ekonomik anlamda zarar oluşturabileceği belirlenmiştir. Laboratuvar koşullarında, zararlının meyve içerisinde gelişmesini tamamlayabildiği ve literatürde bildirilen diğer konukçuları kadar bir sürede bunu başarabildiği belirlenmiştir. Mücadelesi için kültürel önlemlerin de yer aldığı kitlesel tuzaklama ve kimyasal mücadele ile birlikte uygulanacak bir entegre mücadele programının etkili sonuçlar verebileceği düşünülmektedir. Çalışmanın yapıldığı hünnap bahçesi, belirtildiği üzere çok izole bir bahçe olmasına karşın, $C$. capitata erginlerinin bir şekilde buraya ulaşabildikleri ve kısa sürede yerleşik bir popülasyon oluşturabildikleri saptanmıştır. Bu nedenle, genel anlamdaC. capitata ile mücadelede üreticiler açısından zamanlama ve birlikte mücadeleye başlama organizasyonları büyük önem taşımaktadır.

\section{KAYNAKLAR}

Akman K, Zümreoğlu A (1973) Ege Turunçgillerinde Akdeniz Meyve Sineği (Ceratitis capitata Wiedemann)' nin Surveyi. Zirai Mücadele Araştırma Yıllı̆̆ı 7: 200.

Başpınar H, Çakmak I, Koçlu T, Başpınar N (2009) Aydın ilii Meyve Bahçelerinde Akdeniz Meyve Sineği, Ceratitis capitata (Wiedemann) (Diptera: Tephritidae)' nin Biyo-Ekolojisi, Zararı, Yayılışı ve Turunçgil Bahçelerinde Savaşımı Üzerinde Çalışmalar. TOVAG 1050178 nolu Proje 56-57s.

Davis P.H., 1967. Flora of Turkey and The East Aegean Islands. Edinburg University Press No: 6, pp. 111-133, U.K.

Demirdere A (1961) Çukurova Bölgesinde Akdeniz Meyve Sineği (Ceratitis capitata Wiedemann)' nin Biyolojisi ve Mücadelesi Üzerinde Çalışmalar. Tarım Bakanlığı,Zirai Mücadele ve Zirai Karantina Umum Müdürlüğü, Ankara, $118 \mathrm{~s}$.

Ecevit MF, Hallaç F, Dilmaç ÜT (2002) Denizli İli Çivril ilç̧esi Gümüşsu Yöresinde Yetişmekte Olan Ünnap (Ziziphus jujuba Mill.)' In Seleksiyon Yoluyla Islahı Üzerinde Araştırmalar. TÜBITAK TOGTAG-TARP-1988, Ankara, $42 \mathrm{~s}$.

İleri M (1961) Türkiye'de Akdeniz Meyve Sineği Durumu ve Mücadelesi. Tarım Bakanlığı, Ankara Zirai Mücadele Enstitüsü Md. Yayını, Ankara, $38 \mathrm{~s}$.

Kızılyamaç S (2016) Farklı Yükseltilerdeki Akdeniz Meyve Sineği, Ceratitis capitata Wiedemann (Diptera: Tephritidae) Popülasyonlarının Biyo-EkolojisiÜzerine Araştırmalar. Çukurova Üniversitesi Fen Bilimleri Enstitüsü, Yüksek Lisans Tezi (Basılmamış), Adana.

Li JW, Ding SD, Ding XL (2005) Comparison of Antioxidant Capacities of Extracts from Five Cultivars of Chinese Jujube. Process Biochemistry, 40 (11): 3607-3613.

Papadopoulos NT, Katsoyannos BI, Kouloussis NA, Hendrichs J, Carey JR, Heath RR (2001) Early Detection and Population Monitoring of Ceratitis capitata(Diptera: Tephritidae) in a Mixed-fruit Orchard in Northern Greece. Journal of Economic Entomology. 94 (4): 971-978.

Özkan C (1993) Doğu Akdeniz Bölgesinde Akdeniz Meyve Sineği Ceratitis capitata (Wiedemann) (Diptera: Tephritidae)' nın Konukçu Değişimi Üzerine Araştırmalar. Çukurova Üniversitesi Fen Bilimleri Enstitüsü, Yüksek Lisans Tezi (Basılmamış), Adana.

Özkan Hi(2017). Hünnap (Zizyphus jujuba Mill.) Meyvesinin Bazı Biyokimyasal Bileșenleri ile Antibakteriyel, Hipoglisemik ve Total Antioksidan Aktivitesinin Incelenmesi. Balıkesir Üniversitesi, Sağlık Bilimleri Enstitüsü, Tıbbi Biyokimya Anabilim Dalı, Yüksek Lisans Tezi. 
Tezcan H, Zümreoğlu A (1986) Laboratuvar Koşullarında Üretilen Ceratitis capitata (Wiedemann) (Diptera: Tephritidae) Popülasyonlarındaki Bazı Kalite Parametreleri Üzerine Araştırmalar. Türk. Bitki Kor. Derg., 10 (4): 237-243.

Tiring G (2015) Ceratitis capitata Wied. (Diptera: Tephritidae)' nın Balcalı (Adana)' da Farklı Meyve Bahçelerindeki Popülasyon Dalgalanması ve Laboratuvar Koşullarında Sıcaklığın Gelişme Süresine Etkisi. Çukurova Üniversitesi Fen Bilimleri Enstitüsü, Bitki Koruma Ana Bilim Dalı (Yüksek Lisans Tezi), Adana.

TÜik (2019) T.C. Başbakanlık Türkiye İstatistik Kurumu, Bitkisel Üretim İstatistikleri, Ankara. www.tuik.gov.tr. Erişim Tarihi: 10.04.2019.

Yao S (2012) Jujube: Chinese Date in New Mexico. NM State University, Cooperative Extension Service.
Weems HV (1981) Mediterranean Fruit Fly, Ceratitis capitata (Wiedemann) (Diptera: Tephritidae). Plant Industry, Entomology Circular, Florida Department of Agriculture, 230: pp. 8.

Zümreoğlu A (1985) İzmir ve Civarında Turunçgil ve Meyve Ağaçlarında Zarar Yapan Akdeniz Meyve Sineği (Ceratitis capitata Wied.) (Dipt.:Tephritidae)' nin Önemi ve Popülasyon Dalgalanmalarına Etki Eden Faktörler Üzerinde Araştırmalar. Ege Üniversitesi Fen Bilimleri Enstitüsü, Doktora Tezi (Basılmamış), İzmir.

Zümreoğlu A (1990) Standardization of Medfly (Ceratitis capitata Wied.) Trapping for Use in Sterile Insect Tecnique Programmes: Two Year Investigations on The Efficiency of Various Medfly Trapping Systems in Western Part of Turkey. Türk. Entomol. Derg., 14 (3): 155-166. 
